EDITORIAL EDITORIAL

Mortes
violentas:
epidemia do
terceiro
milênio?

Violent deaths: the epidemic of the third millenium?

\section{José da Rocha Carvalheiro}

Com este número a Revista Brasileira de Epidemiologia inaugura duas tendências. A primeira é o lançamento de números especiais, com temas definidos em função de sua relevância epidemiológica ou metodológica. A segunda, representada pelo próprio processo de escolha desses temas, para o qual se exige o fiel cumprimento dos princípios básicos que orientam esta publicação da Abrasco: a participação dos membros da comunidade na escolha dos temas e na indicação dos autores convidados. A idéia básica é a de escolher temas capazes de identificar pontos importantes na área epidemiológica, induzindo o debate e a apresentação de contribuições originais.

Não poderia ter sido melhor a escolha do tema e dos autores. A violência tem sido considerada componente central e preocupante do perfil epidemiológico dos países da Região das Américas. Os autores escolhidos têm larga tradição na área, em particular o Autor Principal, João Yunes, Professor Titular da Faculdade de Saúde Pública, da USP, que tem um invejável currículo tanto no mundo acadêmico quanto no de gestão em saúde pública no Brasil, e de representação dos sanitaristas brasileiros no contexto internacional. Membro da equipe de dirigentes do Ministério da Saúde na década de 70, foi Secretário de Estado da Saúde no primeiro governo eleito democraticamente em São Paulo, no início dos anos 80. Membro do Ministério, teve papel saliente na retomada da tradição de realizar periodicamente as Conferências Nacionais de Saúde, uma delas quase inteiramente dedicada à epidemiologia e controle da xistosomose. No governo estadual determinou o resgate da explícita importância da epidemiologia na organização das ações de saúde ao criar o Centro de Vigilância Epidemiológica (CVE) e o Centro de Vigilância Sanitária (CVS) da Secretaria Estadual de Saúde. Representante da Organização Pan-Americana da Saúde em Cuba e, posteriormente, membro da equipe central da OPS Central em Washington, onde foi Diretor da Divisão de Promoção de Saúde. Foi Diretor da BIREME e esteve
This issue of Revista Brasileira de Epidemiologia (The Brazilian Journal of Epidemiology) sets two new trends. The first is the introduction of special issues, with topics that have been selected according to their epidemiological or methodological importance. The second is the process used for selecting these topics. This requires strictly following the basic principles that guide Abrasco publications: that the members of the community take part in selecting the topics to be included and the authors to be invited. The basic idea is to select topics that identify important issues in the field of epidemiology that can foster discussion and which are original contributions.

The choice of the topic and authors could not have been better. Violence is considered to be the main component, and one of concern in the epidemiological profile of every country in the Region. The authors chosen have vast experience in this field, particularly the main author, João Yunes, a full professor in the School of Public Health (Faculdade de Saúde Pública) of the University of São Paulo (USP) and who has an outstanding resume, both in the academic community and in the area of public health management in Brazil. He also represents Brazilian public health workers at the international level. He was a member of the management staff of the Ministry of Health in the 1970s, and Secretary of the São Paulo State Health Department during the first democratically elected government in São Paulo, in the early 1980s. As a member of the Ministry, he played an important role in reestablishing the tradition of periodically holding national health conferences, one of which was almost entirely dedicated to epidemiology and the control of schistosomiasis. During his term of office in the state government, he was able to give epidemiology its due importance in the organization of health actions by creating the Disease Surveillance Center (Centro de Vigilância Epidemiológica - CVE and Centro de Vigilância Sanitária - CVS) of the State Health Department. As a representative of 
sempre ligado a temas de relevo epidemiológico na Região das Américas da OMS (AMRO/ WHO). Com uma importante produção científica em diversas áreas, especialmente no campo da saúde da mulher e da criança e das estatísticas vitais, dedica-se presentemente à questão da mortalidade por causas externas.

O tema da violência afigura-se como um dos mais importantes no início do século XXI, em particular na Região das Américas. Este fato preocupante pode ser evidenciado na leitura dos Relatórios da situação de saúde produzidos pela OMS e pela OPAS. Os acidentes de trânsito mantêm-se como causa principal de morte por causas externas, porém o aumento impressionante dos homicídios, em particular no grupo de homens jovens e adolescentes, é uma das principais características da situação epidemiológica das Américas. Fazer com que esse tema seja considerado como o principal na discussão das políticas de saúde no continente é uma tarefa que nos espera neste início do terceiro milênio. Evidentemente, não cabe exclusivamente à epidemiologia e à saúde pública a tarefa de estudar a situação e propor ações. Esta é uma questão eminentemente transdisciplinar no âmbito da reflexão teórica e inter-setorial no da proposta de intervenções. A saúde, e por decorrência a epidemiologia, tem um papel a desempenhar que, se não é exclusivo, é profundamente relevante. Quanto mais não seja, porque o resultado da violência crescente impacta fortemente sobre a organização dos serviços de atenção às vítimas e da incorporação de tecnologia, além da melhoria na organização do resgate das vítimas em tempo hábil.

No debate teórico a saúde deve se fazer presente com o seu instrumental epidemiológico. A questão da determinação social dos fenômenos ganha aqui uma relevância extrema. Porém, a tradição epidemiológica da vigilância fundada no registro contínuo de estatísticas vitais segue sendo nossa principal característica. Nesse sentido, os Autores transitam de maneira competente pela questão do sub-registro e sua impor- the Pan-American Health Organization in Cuba and, later as a staff member of the Central Office in Washington, as Director of the Promotion of Health Division, and head of BIREME, the Latin American and Caribbean Center on Health Sciences Information, he has always been associated with relevant epidemiological issues in the regional offices of the WHO in the Americas. (AMRO/WHO). He has made important scientific contributions in different areas, especially in the field of women and children's health and vital statistics. He is presently working on issues dealing with violent deaths. As we enter the twenty-first century, we see that violence is one of the most important topics, mainly in the region of the Americas. This alarming fact stands out in the health status reports produced by WHO and PAHO. Traffic accidents remain the main cause of deaths due to external causes, although the impressive increase in homicides, mainly among young men and adolescents, is one of the main characteristics of the epidemiological situation in the Americas. The main task that lies ahead of us as we enter the third millennium is to make this the main topic of discussion for health policies in the continent. Of course, studying this situation and proposing action is not a task that should fall solely to epidemiology and public health. It is basically a multidisciplinary issue that calls for theoretical and intersectoral thought in terms of the proposal for plans of action. The role to be played by health, and consequently epidemiology, is highly relevant although not exclusive. If for no other reason, this is important because the results of increasing violence have a great impact on the organization of services to assist victims and the incorporation of technology, as well as the need for improved organization for the timely rescue of victims.

Health, and its epidemiological tools, should be part of theoretical discussions. Here, the question of the social determination of phenomena takes on the utmost importance. The epidemiological tradition of surveillance, however, founded on the 
tância quando se buscam comparações internacionais. Pensando na possível incursão pela questão dos determinantes sociais este será um óbvio ponto para aprofundamento futuro. Outra questão que surge imediatamente do texto é relacionada com a absoluta falta de estudos epidemiológicos sobre os eventos violentos que não levam a óbito, mas a incapacitações permanentes com suas repercussões econômicas e, especialmente, no cotidiano da vida de milhares de pessoas jovens nas Américas.

Uma última reflexão deve ser a de quais razões podem fazer com que um continente, com relativamente poucos conflitos bélicos na atualidade, se torne o principal motivo de preocupação das autoridades sanitárias mundiais nesta questão do aumento da mortalidade por causas externas, em particular de homicídios de adolescentes e adultos jovens. Por que estamos matando nossos jovens? continuous recording of vital statistics, continues to be our main feature. In this sense, authors ably work with underrecording and its importance when seeking international comparisons. Bearing in mind the possibility of venturing into the issue of social determining factors, this will obviously be a matter for future in-depth consideration. Another issue that immediately arises from the text is related to the total lack of epidemiological studies of violent events that do not end in death, but in permanent disabling conditions, along with their economic consequences and especially consequences that affect the daily lives of thousands of young people in the Americas.

A last point to consider should be the question of what makes a continent, which is experiencing relatively few military conflicts at this time, become the main cause of concern for world health authorities with regard to the increase in mortality due to external causes, mainly the murder of adolescents and young adults. Why are we killO Editor ing our young people?

The Editor. 